\title{
Impact of the "Belt and Road" Initiative on Chinese Cultural Economy
}

\author{
Hong Wu \\ Xi'an International University, Xi’an, Shaanxi, 710077, China
}

Keywords: “Belt and Road” Initiative; Chinese culture economy; impact

\begin{abstract}
The "Belt and Road" initiative offers a new opportunity to the development of Chinese culture industry, so China should take advantage of this opportunity and identify the strategic value dimension within the layout of "Belt and Road". This strategy has created a tremendous development space for the culture industry and plays an important role in improving the soft power of Chinese culture and its international influential power. Meanwhile, it is a key strategy to influence and optimize the order and layout of world economic and social development. Currently, Chinese cultural industry lies in a key period of transformation. With this strategy, it is necessary to facilitate quality of culture in domestic and enhance cooperation with culture abroad. Specifically, it includes cultivation of specialized cultural industry, perfection of cultural product system and building of cultural trade. The "Belt and Road" initiative is made with comprehensive consideration of the domestic and abroad situation. The rooted problem faced by it is not about politics and economy, but civilization. It covers $63 \%$ global area and about 4.4 billion populations. The heterogeneity of culture offers tremendous tensile force for the prospect of cooperation and great challenge.
\end{abstract}

\section{Introduction}

The strategy "One Belt and One Road" is an objective need for China to melt into world economic system and enhance cooperation with surrounding countries on the aspects of economy, trade and culture. Meanwhile, it is a key strategy to influence and optimize the order and layout of world economic and social development. Currently, Chinese cultural industry lies in a key period of transformation. With this strategy, it is necessary to facilitate quality of culture in domestic and enhance cooperation with culture abroad (Li Huailiang 2003, p.2). Specifically, Currently, Chinese cultural industry lies in a key period of transformation. With this strategy, it is necessary to facilitate quality of culture in domestic and enhance cooperation with culture abroad. Specifically, it includes cultivation of specialized cultural industry, perfection of cultural product system and building of cultural trade. "One Belt and One Road" strategy is made by comprehensively considering the situation in domestic and abroad. The rooted problem faced by it is not about politics and economy, but civilization. It covers $63 \%$ global area and about 4.4 billion populations. The heterogeneity of culture offers tremendous tensile force for the prospect of cooperation and great challenge. The main purpose of this essay is to discuss the impact of this strategy on Chinese cultural economy.

\section{The "Belt and Road" Initiative}

\subsection{Background}

In domestic, this strategy is mainly to balance west and east development. From the domestic perspective, it is hard to find out a good breakthrough to solve the unbalance development between east and west (Jeongho Oh 2001, p.1). Shanghai Economic and Trade Zone faces developed countries and the whole world, Kashgar Economic and Trade Zone faces the mainland and developing countries. Therefore, besides Silk Road Economic Belt, China has formulated multiple plans, such as China Pakistan Economic Corridor, China India Myanmar Bangladesh Economic Corridor. However, except those unbalanced factors of economic development, many unbalanced problems still exist in terms of relation between China and foreign countries (Ge Zhaoguang 2011 p.15). Thus, it is urgent to implement this strategy to solve those unbalanced problems. It is an 
urgent need to implement this strategy to solve those unbalanced problems. It is well-known that after China joined WTO, it has achieved more profits than that of west countries (Jeongho Oh 2001, p.1). If the negotiation of " $3 T^{\prime}$ " is successful, high standard trade and investment service system will be built. At the same time, the world economy antenna established by China during the past 30 years may be rejected out of world gate because of too low principle (Haltmaier 2013, p.58). At that time, China may lose its power in world economic stage and the space of globalization will also be shrunk (Jeongho Oh 2001, p.1). Therefore, this strategy is a need for China to handle the new economic order in the world. In July 2011, American United States Secretary of State Hillary proposed strategy of New Silk Road, which aroused international attention(Haltmaier 2013, p.48). The target of this strategy is to centered in Afghanistan and connect Central Asia and South Asia. Its intention does not just refer to a single line economy, but refers to formulate extensive regional traffic and economic network, including software and hardware. The essence is to seek for new strategic and economic benefits. Both UK and US has implemented military attack on Afghanistan. In the middle Asia region, severe geopolitics situation emerged (Haltmaier 2013, p.30). In order to aggravate political, economic and military penetration in middle Asia area, US has formulated the bill of amendment and strategy of new middle Asia area and tries to involve middle Asia area into its own economic circle. For the background abroad, new international economic order is being built. In order to avoid the track of an overturned cart, various countries in the world try to adjust economic structure and seek for opportunity of recovery in order to build new international order (Ge Zhaoguang 2011 p.15). Previously, though people had confidence into WTO, the 12-year deadlock negotiation has made international society lose confidence into WTO (Haltmaier 2013, p.52).

\subsection{Connotation}

The strategy of "One Belt and One Road" should be based on economic cooperation and supported by people-to-people exchanges and it also includes the ideology of openness and containment (Teagarden 2014, p.391). Especially, “One Belt and One Road” connects the regions of middle Asia, South Asia, South East Asia and west Asia, which is beneficial for the communication between different regions and then build and perfect supplying chain, industry chain and value chain (Zhang Xiping 2015 p.12). The key point of near-term target is the building of road, energy pipe lines, telecommunication and port in order to improve the convenience degree of trade and investment. The middle term target is to march into countries and regions with mature conditions and create the updating version of ASEAN-China Free Trade (Teagarden 2014, p.392). Then, it builds Free Trade Zone with middle Asian countries and includes African east coast and Latin American region into cooperation mechanism. Finally, long-term target is to build free trade zone group which covers middle Asia, South Asia, West Asia, Europe, Africa and Latin countries (Jin Wei 2016 p.56). According to foreign experts, ancient Chinese silk road facilitated dialogue and melting of different civilizations and the conception of "One Belt and One Road" enriches this connotation and manifests the innovation of Chinese global strategy.

\section{Impact of the “Belt and Road” Initiative on Chinese Cultural Economy}

\subsection{Function of the "Belt and Road" Initiative}

In the vision and action file issued by Chinese government, it especially emphasizes the civilization, tolerance, respecting developing mode of each country and enhancing the dialogue between different civilizations. It can be said that not only "One Belt One Road" strategy is an economic strategy, but also it is a cultural strategy and it plays an important role in rising of Chinese culture (Teagarden 2014, p.392). “One Belt One Road” is a dual core strategy about economic trade and cultural development. No matter it is Silk Road Economic Belt or 21st Century Maritime Silk Road, it contains the important content based on economic cooperation and humanistic communication. The relationship between each country needs to be supported by economic and trading cooperation as well as cultural communication. In this sense, not only this 
strategy is an economic strategy of openness, but also it is an important cultural strategy to realize the going out of Chinese culture (Jin Wei 2016 p.56). By implementing this strategy, it is beneficial to deepen cultural communication and trading interaction between related countries, promote regional cooperation and realize long term development. As a result, each country along the line can absorb reasonable content of alien culture and facilitate the development of different civilizations.

"One Belt One Road" offers historical opportunity for the expansion of cultural industry. As cultural consumption needs wide market, the more extensive the main body of consumption, the more extensive the communication of culture and the influential power of culture (Teagarden 2014, p.392). The strategy of "One Belt One Road" makes people with different cultural background and religions communicate with each other more smoothly and offers an optimized route to make various kinds of excellent cultures develop in harmony. The great-leap-forward development of cultural industry needs to take full advantage of two markets and resources in domestic and abroad and also it requires that cultural industry actively participates into international labor division and transformation in order to enter higher level of global cultural industrial value chain (Jin Wei 2016 p.56). In this sense, as an important carrier of combined strategy of culture and economy, “One Belt and One Road" strategy plays an important role in pushing Chinese culture to walk out.

“One Belt and One Road” strategy helps to dredge channels for the melting and innovation of culture in each country. Various economic development degree and social political background make culture in each country and region colorful and diversified (Park 2008, p.50). While this kind of difference and conflict brings great variables, it also predicts bigger cultural development space because the motivation mechanism of cultural development is cultural communication, collision, melting and innovation. During the process of historical evolution, Chinese traditional culture highlights its national specialty in China and foreign exchange and is also affected by alien culture. In this way, it realizes its growth and innovation in this kind of collision. The key point of "One Belt One Road" is the groupment reviving of each related country and diversified civilization (Park 2008, p.51). It is established on basis of civilized melting rather than civilized conflict. Thus, it requires that each related countries must enhance the openness level of culture and makes ancient civilization have new vitality in modern society. And this kind of melting will offer firm basis for regional economic integration.

In history, not only Silk Road was the channel for trade, but also it was a road for cultural exchange and it represented the process of original globalization. Looking back the history of Silk Road, ancient Persian culture, ancient Roman culture, ancient Greek culture, Arabic culture, ancient Indian culture and ancient Chinese culture communicated and collided with each other (Tomlinson 1999, p.30). With the trade of commodity, the population migration happened between China and alien nationalities and they also undertook communications in terms of politics, religion, art and life style. It can be seen that Silk Road was established by multiple nationalities and merchants from middle Asia, Persia and Abrabic area has made great contributions to Silk Road. The birth of Chinese Uyghur nationality and the Hui nationality witnesses the huge input of alien nationality and European and Asian nationality (Tomlinson 1999, p.30). Silk Road is not the single direction invasion of powerful culture, but the dual directional flowing of different cultures.

Why Silk Road is hard to be dust-laden or buried by history lies in its original mode of exploring and creating civilized communication in human history to a great extent. The strategy of "One Belt and One Road" is not just an economic event relevant to profits of each country, but a cultural event to arouse resonance of each country. The essence of this strategy is quality and inclusiveness, which represents the development tendency of non-polar and de-marginalization and transcends the cultural polar thinking of developed capitalism country. After second world war, western people started to challenge the centeredness theory of western culture. In November 2011, Universal Declaration on Cultural Diversity passed by UNESCO pointed out that cultural diversity means that the common heritage culture of human beings have different manifestations forms in different eras and places.Cultural diversity is the source of communication, revolution and creation and it is essential for human beings to maintain biological balance. From this sense, cultural diversity is the common heritage of human beings and should consider profits of current generations and later 
generations. The building of "One Belt and One Road" respects the development mode of each country and stresses the dialogue between different civilizations. The future of Chinese culture is certain to go out and in this process, the world is melting China and absorbs factors of China (Srivastava 2009, p.107). The cultural meaning of "One Belt One Road" is to adhere to the communication and sharing mode of original globalization and caters for the common recognition to maintain cultural diversity. Besides the strategy of "One Belt and One Road" is a kind of creative strategic designing, it is also a kind of beautiful cultural vision.

\subsection{Issues relevant to implementation of the "Belt and Road" Initiative}

In the process of implementing "One Belt One Road" strategy, to go out is a macro strategic layout and a practical pusher. Several issues must be considered. Firstly, transform traditional oneway communication method and formulates dual direction cooperation layout. Under the current international situation, culture's going out has not been a process from the internal to external in a single direction. Thus, powerful promotion or one-way communication method usually leads to not ideal result and affects the effects of going out of culture or even the political ethics between countries (Haltmaier 2013, p.49). Since culture is interactive, in order to break through this kind of one-way communication method, even if culture on one side has gone out, it still needs mutual interaction, understanding, respect and mutual win-win. In this sense, strategy of "one belt and one road" does not just copy the ancient Silk Road, but pays attention to reply on the cultural characteristics of region, development characteristics, resources and advantages of system to formulate resultant forces (Haltmaier 2013, p.49). It does not mean exploring respective competitive force through a set of non different or standard market entry, management mode and management procedure, but inherits function of trade interaction and cultural communication.

The fact is that some cultural projects of China are resisted by western countries. Undeniably, some actions are out of political purpose, but it should be noted that we are lack of awareness of product competition (Teagarden 2014, p.392). The commodity production and consumption should participate into competition according to principles of international market. Added with the promotion of cultural value, a kind of win-win situation will be formulated. Thirdly, change the participation method in which just one single main body exists, but it needs to formulate active and enriched communication levels. In pushing forward the process of cultural communication, previous government does not take full advantage and integrate some public resources, such as multinational companies, international public company and non-government organization (Teagarden 2014, p.391). Actually, it is not enough that Chinese folk organization and citizen individual participate into cultural promotion so that the channels of cultural trade and international telecommunication is just in the initial step. The traditional cultural communication channel dominated by government appears to be single and its effect needs to be discussed in further step (Haltmaier 2013, p.58). At the same time, as regards company itself, product culture, corporate culture and value culture are not enough, which usually makes a negative impression of China.

\section{Conclusion}

In summary, the strategy of "One Belt and One Road” should be based on economic cooperation and supported by people-to-people exchanges and it also includes the ideology of openness and containment. In carrying out this strategy to make culture go out, government should consider deeply on the macro level. Traditional cultural resources should be excavated fully. As long as traditional cultural resources are expressed comprehensively and accurately, Chinese culture can go out smoothly and then makes a great contribution to human civilization. It is necessary to study the customs, national habits, cultural source, aesthetic interest and fashion of each country, consider consumption habits and custom factors under each kind of cultural background and cultural tradition of different audiences. Then, their common interests can be found and launch suitable cultural products and services and formulate cultural brands. It also needs to take full advantage of comparative advantages of each country, excavate historical and cultural heritage and guide folk forces to launch enriched cultural and communicative activities. 


\section{Acknowledgement}

This work is supported by the "Research on the Development of Xi'an Art Market" (code:15JK 2132) Project Resource: Xi'an Social Fund Project in 2017, Project Name: Status Analysis of Preschool Education and Study on its Development: Take Xi'an High-tech Zone of Economy for example Name Code: $17 \mathrm{~N} 16$

\section{References}

[1] Jeongho Oh. International trade in film and the self-sufficiency radio. The Journal of Media Economics, 2001,14(1).

[2] Haltmaier J. Challenges for the future of Chinese economic growth[J]. Ssrn Electronic Journal, 2013.

[3] Teagarden M B. The New Silk Road[J]. Thunderbird International Business Review, 2014, 56(5): 391-392.

[4] Park Y S, Kim B S. Asian and European American cultural values and communication styles among Asian American and European American college students. [J]. Cultural Diversity \& Ethnic Minority Psychology, 2008, 14(1): 47-56.

[5] Tomlinson J. Globalization and culture[J]. Contemporary Sociology, 1999, 30(6).

[6] Srivastava M, Gips B J. Chinese Cultural Implications for ERP Implementation[J]. Journal of Technology Management \& Innovation, 2009, 4(1): 105-113. 